\title{
BIOACTIVE COMPOUNDS IN CONVENTIONAL AND NO ADDED SUGARS RED STRAWBERRY GUAVA (Psidium cattleianum Sabine) JELLIES ${ }^{1}$
}

\author{
GABRIELA NIEMEYER REISSIG ${ }^{2}$, LISIANE PINTANELA VERGARA ${ }^{3}$, \\ RODRIGO CEZAR FRANZON ${ }^{4}$, ROSANE DA SILVA RODRIGUES ${ }^{5}$, JOSIANE FREITAS CHIM ${ }^{6}$
}

ABSTRACT - This study aimed to prepare jellies of conventional type of red strawberry guava (with added sucrose) and no added sugar and evaluate the physical and chemical composition and content of bioactive compounds in them. Four jellies formulations were prepared: conventional with addition of sucrose (F1), aspartame (F2), saccharin and cyclamate (F3), acesulfame and sucralose (F4). Physicochemical analysis of $\mathrm{pH}$ were carried out, as well as analysis of titratable acidity, total soluble solids, ashes, proteins, lipids, moisture, carbohydrates, calories, lightness, color tone, total phenols, anthocyanins, carotenoids, ascorbic acid and antioxidant activity, by the capture of DPPH and ABTS radicals. Conventional and no added sugars jellies did not differ for total phenols, total anthocyanins and ascorbic acid. However, processing exerted significant influence $(\mathrm{p} \leq 0.05)$ on total carotenoids and antioxidant activity. It is feasible to use red strawberry guava for the preparation of conventional and no added sugar jellies. The products, however, show a significant difference in carotenoids content, with the highest content of these and higher antioxidant activity in processed jellies without sugars addition.

Index terms: native fruits, processing, phytochemicals, special purpose foods.

\section{COMPOSTOS BIOATIVOS EM GELEIAS DE ARAÇÁ VERMELHO (Psidium cattleianum Sabine) CONVENCIONAL E SEM ADIÇÃO DE AÇÚCARES}

\begin{abstract}
RESUMO - Objetivou-se elaborar geleias de araçá vermelho do tipo convencional (com adição de sacarose) e sem adição de açúcares e avaliar a composição físico-química e teores de compostos bioativos presentes nas mesmas. Foram elaboradas quatro formulações de geleias: convencional com adição de sacarose (F1); com adição de aspartame (F2); com adição de sacarina e ciclamato (F3); com adição de acessulfame e sucralose (F4). Foram realizadas análises físico-químicas de $\mathrm{pH}$, acidez total titulável, sólidos solúveis totais, cinzas, proteínas, lipídios, umidade, carboidratos, valor calórico, luminosidade, tonalidade de cor, fenóis totais, antocianinas totais, carotenoides totais, ácido ascórbico e atividade antioxidante pela captura dos radicais DPPH e ABTS. As geleias convencional e sem adição de açúcares não diferiram para fenóis totais, antocianinas totais e ácido ascórbico. Contudo, o processamento exerceu influência significativa $(\mathrm{p} \leq 0,05)$ sobre carotenóides totais e atividade antioxidante. É viável a utilização de araçá vermelho para elaboração de geleias convencional e sem adição de açúcar. Os produtos, contudo, apresentam diferença significativa quanto aos teores de carotenóides, sendo os maiores teores destes e maior atividade antioxidante nas geleias processadas sem adição de açúcares.
\end{abstract}

Termos de indexação: frutos nativos, processamento, fitoquímicos, alimentos para fins especiais.

\footnotetext{
${ }^{1}$ (Trabalho 062-15). Recebido em:09-03-2015. Aceito para publicação em: 29-07-2015.

${ }^{2}$ Química de Alimentos, Mestre em Ciência e Tecnologia de Alimentos/UFPel, Pelotas-RS. E-mail:gabriela.niemeyer.reissig@gmail.com ${ }^{3}$ Tecnóloga em Agroindústria, Mestre em Ciência e Tecnologia de Alimentos/UFPel, Pelotas-RS. E-mail:lisianevergara@yahoo.com.br ${ }^{4}$ Engenheiro Agrônomo, Dr. em Agronomia, Pesquisador Embrapa Clima Temperado, Pelotas-RS. E-mail: rodrigo.franzon@embrapa.br ${ }_{5}^{5}$ Engenheira Agrônoma, Dra. em Tecnologia de Alimentos, Professora associada II, CCQFA/UFPel, Pelotas-RS. E-mail: rosane.rodrigues@ufpel.edu.br

${ }^{6}$ Química de Alimentos, Dra. em Ciência e Tecnologia de Alimentos, Professora adjunta do CCQFA/UFPel, Pelotas-RS. E-mail: josianechim@gmail.com
} 


\section{INTRODUCTION}

Brazil is one of the largest fruits producers in the world, along with China and India. According to data from the Brazilian Fruit Institute (IBRAF, 2013), in 2013 Brazil exported 711.8 thousand tons of fresh fruit. Even with a great biodiversity of flora, with many native fruit species, many of these fruits are little used and commercially valued, as is the case of strawberry guava. The strawberry guava (Psidium cattleianum Sabine) is a globular berry, yellow or red, with juicy pulp presenting very pleasant sweetsour flavor and well accepted by consumers. Studies show that the fruits of strawberry guava are rich in bioactive compounds, especially phenolics and carotenoids. Strawberry guava is widely distributed in various regions of the country, from Rio Grande do Sul to Bahia, and has been grown in home gardens. However, its high perishability limits the marketing in natura (FRANZON et al., 2009; LORENZI et al., 2006).

The use of native fruits like strawberry guava for jellies preparation is an alternative to take advantage of the fruit and for small family businesses and agroindustries diversify their products. Besides the conventional process of jellies, which technology is already known and feasible, its development is possible without the addition of sugar (essential ingredient to the gel formation in the conventional process).

The preparation of jellies without sugars is a way to diversify and meet the demands of the consumer market that is increasingly seeking for quality and differentiated products, particularly with high nutrient content and lower caloric value, either for aesthetic reasons, physiological or healthiness restrictions

Similarly has been valued by consumers those foods with potentially bioactive compounds wich can act to reduce the risk of the occurrence of some nontransmissible chronic diseases due to the antioxidant, anti-diabetes and anti-inflamatory capacity of these compounds (KAMILOGLU et al., 2015b; PEREIRA e CARDOSO, 2012). However, such secondary compounds derived from the specialized metabolism of plants may be sensitive to processing and storage.

The preparation of jellies involves the application of heat, wich may cause substantial losses in product quality, nutrients and bioactive compounds content (KAMILOGLU et al., 2015a; NORA et al., 2014). Therefore, the objective was to prepare jellies and evaluate the content of bioactive compounds in conventional (with sucrose) and no added sugar red strawberry guava jellies.

\section{MATERIAL AND METHODS}

Red strawberry guava fruits used in this study were donated by Embrapa Temperate Climate, from Pelotas, Rio Grande do Sul (RS) state (geographical coordinates: $31^{\circ} 40^{\prime} 47^{\prime \prime} \mathrm{S}$ and $52^{\circ} 26^{\prime} 24^{\prime \prime} \mathrm{W}: 60 \mathrm{~m}$ altitude). The fruits were washed, sanitized with chlorine solution at $200 \mathrm{ppm}$ and pulped in horizontal removing device belonging to the industrial plant of IFSUL- Visconde da Graça Campus, Pelotas (RS).

The jellies processing was performed after the preparation of the pulp with the following formulations: one conventional formulation (F1) and three no added sugars formulations. In each no added sugars formulations was used specific type of sweeteners: aspartame (F2); sodium saccharine and sodium cyclamate (F3); potassium acesulfame and sucralose (F4). All formulations were prepared in the food processing laboratory of CCQFA-UFPel.

For conventional jelly formulation (F1) was used $(\% \mathrm{~m} / \mathrm{m})$ : 50 red strawberry guava pulp, 50 commercial sucrose, 40 distilled water, 0.7 ATM pectin, 0.2 citric acid, 0.05 sodium benzoate and 0.25 sodium erythorbate. For no added sugars jellies formulations was used the same amount of red strawberry guava pulp used for conventional formulation. The formulation used was $(\% \mathrm{~m} / \mathrm{m}): 40$ distilled water, 2.5 BTM pectin, calcium chloride (50 $\mathrm{mg} / \mathrm{g}$ of BTM pectin), 65 sorbitol, specific sweeteners for each formulation (F2: aspartame - 0.13; F3: sodium saccharine and sodium cyclamate - 0.03 and 0.07 , respectively; F4: potassium acesulfame and sucralose -0.06 and 0.07 , respectively), 0.2 citric acid, 0.05 sodium benzoate and 0.25 sodium erythorbate.

The jellies processing were similar, just changing the ingredients used, the concentration time and final soluble solids $\left(68^{\circ}\right.$ Brix for conventional jelly and $48^{\circ}$ Brix for no added sugars jellies). The BTM pectin, sorbitol and calcium chloride were added to the formulations without addition of sugars with the aim of replacing sucrose, enabling gel formation and improving the texture of the product.

The jellies processing temperature was 80 $85^{\circ} \mathrm{C}$ and it was raised to $90^{\circ} \mathrm{C}$ immediately before filling. The conventional processing time was 1 hour and 15 minutes and no added sugars formulations were processed in 2 hours. The jellies were filled into glass containers with capacity of $248 \mathrm{~mL}$ and tin plate lids, previously sterilized $\left(100^{\circ} \mathrm{C} / 10\right.$ minutes glasses and $100^{\circ} \mathrm{C} / 5$ minutes covers). After filling, the glasses with jellies were reversed for 5 minutes and then pasteurized in a water bath $\left(80^{\circ} \mathrm{C} / 10\right.$ minutes $)$ 
and, subsequently, cooled under running water. The storage was at room temperature $\left(20-22^{\circ} \mathrm{C}\right)$. The $\mathrm{pH}$, titratable acidity, total soluble solids, moisture, ashes, lipids, proteins and total carbohydrates (by difference) were performed according to methods described in Analytical Standards of Adolfo Lutz Institute (2008). The caloric value was calculated according to Anvisa (2005) guidelines.

Color determination was performed using a Minolta colorimeter CR-300, for the CIE System ( $\mathrm{L}^{*}$ $\left.a^{*} b^{*}\right)$, by direct reading of the $L^{*}$ values (lightness) ranging from 0 (black) to 100 (white); $a^{*}$, green $(-)$ to red $(+)$; b*, blue $(-)$ to yellow $(+)$. The color parameters were used to calculate the Hue angle $\left({ }^{\circ} \mathrm{Hue}=\tan -1\left(\mathrm{~b}^{*} / \mathrm{a}^{*}\right)\right.$.

For total phenolics compounds analysis was used procedure described by Singleton and Rossi (1965), with modifications. For total anthocyanins was carried out the method described by Lee and Francis (1972), with modifications. The total carotenoids were determined by the modified method 970.64 from AOAC (2005). The ascorbic acid (L-ascorbic acid) analysis was accomplished through the metodology proposed by Vinci et al. (1995), with adaptations. The antioxidant activity for the capture of DPPH radical was determined by adapted method from Brand-Williams et al. (1995). The antioxidant activity using ABTS radical was determined by adapted method from Rufino et al. (2007).

All physicochemical analyzes were performed in food biotechnology and secondary metabolism laboratories from DCTA-UFPel. The physicochemical data were submitted to variance analysis (ANOVA) and means comparison by Tukey test $(\mathrm{p} \leq 0.05)$ using STATISTICA 7.0 program (STATSOFT, 2004).

\section{RESULTS AND DISCUSSION}

Table 1 shows physicochemical and caloric value data of conventional and no added sugars red strawberry guava jellies. There was no significant difference in the $\mathrm{pH}$ of the conventional formulation compared to no added sugars formulations. It was expected that no added sugars jellies presented higher $\mathrm{pH}$, probably due to addition of sweeteners, wich tend to raise $\mathrm{pH}$. However, there was a significant difference only between formulations with aspartame and acesulfame/sucralose. Santos et al. (2014), for conventional and diet "cocoa honey" jellies, observed higher $\mathrm{pH}$ values in sucrose and thaumatin/potassium acesulfame jellies formulations when compared with sucralose/acesulfame and thaumatin/sucralose formulations.
There was a higher titratable acidity in formulations without sugars addition, possibly due to the higher concentration of red strawberry guava pulp and, consequently, greater organic acids presence. Guimarães et al. (2014), in conventional and light blueberry jellies, did not observe significant difference in acidity between any treatments in the first storage period

No added sugars jellies showed higher moisture than conventional formulation, wich provided lower soluble solids concentration in this jellies formulations. Santos et al. (2014) also found higher moisture values in "cocoa honey" diet jellies, in comparison with the conventional formulation.

In this study, there was a greater soluble solids concentration and lower moisture in the conventional product compared to the others. This result was expected, since formulations F2, F3 e F4 had no addition of sugars. Similarly, the result obtained for carbohydrates content was higher $(p \leq 0.05)$ in conventional jelly. Regarding to lipids, proteins and ashes, there were higher content of these components in no added sugar formulations. This is probably due to the replacement of sucrose for sweeteners, with consequent increase in pulp percentage in the final product.

Among the elaborate formulations, conventional jelly had the lowest lightness value, differing significantly $(\mathrm{p} \leq 0.05)$ of no added sugars formulations. Kovacevi et al. (2015), in jelly made with strawberry from Elsanta cultivar, found $17.15 \pm 0.87$ of lightness. This value is lower than the obtained in the present study, indicating that the jelly obtained by these authors is darker than the conventional and no added sugars red strawberry guava jellies. Jellies tone color, measured by ${ }^{\circ} \mathrm{Hue}$, was also higher for no added sugars jellies, and the closer to zero ${ }^{\circ} \mathrm{Hue}$, the products tend to redder colors. Thus, the conventional jelly showed more reddish tone than no added sugars jellies. Kovacevic et al. (2015) found in low sugar jellies made with strawberry from Elsanta cultivar $28.73 \pm 1.62{ }^{\circ} \mathrm{Hue}$ value, a result similar to that found in conventional red strawberry guava jelly.

There was a reduction $(p \leq 0.05)$ in caloric values of no added sugars jellies compared to conventional formulation, of $36.23 \%$ (F2), 34.81\% (F3) and $36.41 \%(\mathrm{~F} 4)$, categorizing them as light jellies (BRASIL, 2012).

Table 2 shows the results for phytochemical analysis of conventional and no added sugars red strawberry guava jellies. F1 and F3 formulations differed $(\mathrm{p} \leq 0.05)$ significantly on total phenols content. No difference was observed among the 
other conventional e no added sugars formulations. It was expected lowest concentration of total phenols due to the no added sugar jellies processing require more time, in order to achieve suitable soluble solids content. On the other hand, there is an increase in pulp percentage in no added sugars jellies in relation to conventional formulation, which may have influenced the response. Unlike in the present study, Kamiloglu et al. (2015b) found higher phenolic compounds content in added sugar jellies, not in jellies with sweeteners.

There was no significant difference between conventional and no added sugars treatments on anthocyanins content. Kamiloglu et al. (2015a), unlike the results obtained in this study, noted that black carrot jellies with sweetener showed a lower content of anthocyanins when compared to added sugar jellies. Similarly to what happened in total phenols content, it was expected that no added sugar jellies processing would cause greater losses of these compounds. The jellies formulations differed $(\mathrm{p} \leq 0.05)$ in total carotenoids content. Conventional processing showed a lower content of carotenoids compared with no added sugar processing. Probably the pulp highest concentration, due to no addition of sugar in formulations with sweeteners, was responsible for the highest content of total carotenoids.

The L-ascorbic acid is one of the most important soluble vitamins for human health, known for its antioxidant activity (SPINOLA et al., 2014) and for being a very sensitive vitamin in heat treatments. Conventional and no added sugars red strawberry guava jellies did not differ significantly in ascorbic acid content. The highest pulp concentration in no added sugars jellies may have compensated the possible losses of ascorbic acid in the processing, as suggested for the other phytochemicals analyzed.

Native fruits, as strawberry guava, are excellent sources of antioxidant compounds and the capacity of these compounds may be evaluated by different methods, such as the capture of DPPH (2,2-diphenyl-1-picryl-hydrazil) and ABTS [2,2'-azinobis(3-ethylbenzthiazoline sulfonic acid-6)] radicals. The antioxidant activity showed significant differences $(p \leq 0.05)$ between conventional and no added sugars treatments, both for the DPPH and ABTS radicals. No added sugars formulations showed the highest values, different than observed for Kamiloglu et al. (2015a), where formulation with sugar showed a higher antioxidant activity by DPPH method than no added sugar formulation at $25^{\circ} \mathrm{C}$. Probably the highest percentage of pulp resulting from no addition of sugars may be primarily responsible for increased antioxidant activity of these products, even with the heat exposure of no added sugars jellies being higher.

The antioxidant activity by DPPH radical was positively correlated with total phenols for all formulations, with the smallest of $\mathrm{r}=0.98$ for aspartame formulation and the highest of $r=0.99$ for acesulfame/sucralose formulation. For the ABTS radical, all formulations showed a positive correlation of $r=0.99$ with total phenols. There was not correlation of the antioxidant activity with the other evaluated phytochemicals. 
TABLE 1 - Physicochemical characterization and caloric value of conventional and no added sugars red strawberry guava jellies.

\begin{tabular}{|c|c|c|c|c|}
\hline & F1 & F2 & F3 & F4 \\
\hline $\mathrm{TSS}^{1}$ & $68,67^{\mathrm{a}}$ & $46,83^{c}$ & $48,17^{\mathrm{b}}$ & $47,17^{\mathrm{c}}$ \\
\hline $\mathrm{pH}$ & $3,76^{\mathrm{ab}}$ & $3,78^{\mathrm{a}}$ & $3,76^{\mathrm{ab}}$ & $3,75^{\mathrm{b}}$ \\
\hline $\mathrm{TA}^{2}$ & $0,97^{\mathrm{c}}$ & $1,40^{\mathrm{a}}$ & $1,20^{\mathrm{b}}$ & $1,20^{\mathrm{b}}$ \\
\hline Moisture $^{3}$ & $33,67^{\mathrm{c}}$ & $57,79^{\mathrm{a}}$ & $56,81^{\mathrm{b}}$ & $57,91^{\mathrm{a}}$ \\
\hline Lipids $^{3}$ & $0,58^{\mathrm{b}}$ & $0,65^{\mathrm{a}}$ & $0,66^{\mathrm{a}}$ & $0,67^{\mathrm{a}}$ \\
\hline Protein $^{3}$ & $0,31^{\mathrm{b}}$ & $0,57^{\mathrm{a}}$ & $0,58^{\mathrm{a}}$ & $0,58^{\mathrm{a}}$ \\
\hline Ashes $^{3}$ & $0,26^{\mathrm{b}}$ & $0,42^{\mathrm{a}}$ & $0,47^{\mathrm{a}}$ & $0,46^{\mathrm{a}}$ \\
\hline Carbohydrates ${ }^{3}$ & $65,18^{\mathrm{a}}$ & $40,56^{\mathrm{bc}}$ & $41,48^{b}$ & $40,39^{c}$ \\
\hline Calorie $^{4}$ & $267,16^{\mathrm{a}}$ & $170,38^{\mathrm{c}}$ & $174,15^{\mathrm{b}}$ & $169,88^{\mathrm{c}}$ \\
\hline Lightness (L*) & $27,19^{c}$ & $36,28^{\mathrm{a}}$ & $36,68^{\mathrm{a}}$ & $34,50^{\mathrm{b}}$ \\
\hline Hue angle $\left(\mathrm{h}_{\mathrm{ab}}\right)^{* *}$ & $28,19^{\mathrm{b}}$ & $51,06^{\mathrm{a}}$ & $50,33^{\mathrm{a}}$ & $50,37^{\mathrm{a}}$ \\
\hline
\end{tabular}

${ }^{1}$ Total soluble solids $\left({ }^{\circ} \mathrm{Brix}\right) .{ }^{2}$ Titratable acidity expressed as citric acid $\left(\mathrm{g} .100 \mathrm{~g}-{ }^{1}\right) .{ }^{3}$ Expressed as percentage.${ }^{4} 100 \mathrm{~g}$ portion, expressed as Kcal. *Lightness $\left(\mathrm{L}^{*}\right) .{ }^{* * \mathrm{o}} \mathrm{Hue}-\mathrm{Hue}$ Angle. Means followed by the same letters on the same line do not differ by Tukey test (p $\leq 0.05$ ). $\mathrm{F} 1=$ conventional; F2=aspartame; F3=saccharin+cyclamate; F4=acesulfame+sucralose.

TABLE 2 - Total phenols (TF), total anthocyanins (TA), total carotenoids (TC), DPPH (antioxidant activity), ABTS (antioxidant activity) and ascorbic acid (AA) of conventional and no added sugars red strawberry guava jellies.

\begin{tabular}{lcccc}
\hline & F1 & F2 & F3 & F4 \\
\hline $\mathrm{TF}^{1}$ & $117,59^{\mathrm{b}}$ & $120,31^{\mathrm{ab}}$ & $123,31^{\mathrm{a}}$ & $20,31^{\mathrm{ab}}$ \\
$\mathrm{TA}^{2}$ & $2,47^{\mathrm{ab}}$ & $2,38^{\mathrm{b}}$ & $2,59^{\mathrm{a}}$ & $2,38^{\mathrm{b}}$ \\
$\mathrm{TC}^{3}$ & $26,00^{\mathrm{c}}$ & $27,10^{\mathrm{a}}$ & $26,47^{\mathrm{b}}$ & $26,93^{\mathrm{a}}$ \\
$\mathrm{AA}^{4}$ & $2,67^{\mathrm{a}}$ & $2,09^{\mathrm{a}}$ & $2,32^{\mathrm{a}}$ & $2,29^{\mathrm{a}}$ \\
DPPH $^{5}$ & $405,61^{\mathrm{b}}$ & $457,29^{\mathrm{a}}$ & $457,30^{\mathrm{a}}$ & $461,80^{\mathrm{a}}$ \\
ABTS $^{5}$ & $49,82^{\mathrm{b}}$ & $63,46^{\mathrm{a}}$ & $65,56^{\mathrm{a}}$ & $63,28^{\mathrm{a}}$ \\
\hline
\end{tabular}

${ }^{1} \mathrm{mg}$ of gallic acid $100 \mathrm{~g}^{-1}$ fresh weight. ${ }^{2} \mathrm{mg}$ of cyanidin 3 -glucoside $100 \mathrm{~g}^{-1}$ fresh weight. ${ }^{3} \mu \mathrm{g}$ of $\beta$-carotene $\mathrm{g}^{-1}$ fresh weight. ${ }^{4} \mathrm{mg} .100 \mathrm{~g}^{-1}$ L-ascorbic acid fresh weight. ${ }^{5} \mathrm{mg}$ trolox equivalent $100 \mathrm{~g}^{-1}$ fresh weight. Means followed by the same letters on the same line do not differ by Tukey test $(\mathrm{p} \leq 0.05)$. F1=conventional; F2=aspartame; F3=saccharin+cyclamate; F4=acesulfame+sucralose.

\section{CONCLUSION}

It is feasible to use red strawberry guava fruits for conventional and no added sugars jellies preparation. The jellies without addition of sugars show higher carotenoids content and higher antioxidant activities, an appeal to the consumption of this type of product.

\section{ACKNOWLEDGEMENTS}

The authors thank CAPES for granting postgraduate scholarship, Embrapa Temperate Climate (Pelotas/RS) for providing red strawberry guava fruits and MasterSense ${ }^{\circledR}$ and CPKelco ${ }^{\circledR}$ by sweeteners and low methoxylation pectin donated. 


\section{REFERENCES}

AOAC, Official methods of analysis of the Association of Official Analytical Chemists. $18^{\text {th }}$ ed. Gaithersburg, 2005.

BRAND-WILLIANS, W.; CUVELIER, M. E.; BERSET, C. Use of a free radical method to evaluate antioxidant activity. Food Science and Technology, London, v.28, p.25-30, 1995.

BRASIL. Ministério da Saúde. Agência Nacional de Vigilância Sanitária. Rotulagem nutricional obrigatória: manual de orientação às indústrias de alimentos $-2^{\circ}$ versão. Brasília, 2005. 44 p. mudar p.5 linha 20 de Anvisa (2005) para Brasil (2005)

BRASIL. Ministério da Saúde. Agência Nacional de Vigilância Sanitária. Resolução RDC n ${ }^{0} 54$, de 12 de novembro de 2012. Regulamento Técnico sobre informação nutricional complementar. Disponível em: <http://portal. anvisa.gov.br/wps/wcm/connect/630a98804d7065b 981fle1c116238c3b/Resolucao+RDC+n.+54 2012. pdf?MOD=AJPERES $>$. Aceso em: 13 fev. 2015 .

FRANZON, R. C.; CAMPOS, L. Z. O.; PROENÇA, C. E. B.; SOUSA-SILVA, J. C. Araçás do gênero Psidium: principais espécies, ocorrência, descrição e uso. Planaltina: Embrapa Cerrados, 2009. 48p. Disponível em: <http://www.cpac.embrapa.br/ noticias/artigosmidia/publicados/133/>. Acesso em: 20 nov. 2013

GUIMARÃES, D. H. P.; ALVES, G. L.; QUERIDO, A. F. Geleia de mirtilo (Blueberry): análises dos parâmetros sensoriais e do efeito do armazenamento nas propriedades físicas e químicas. Revista Brasileira de Pesquisa em Alimentos, Campo Mourão, v.5, n.1, p.19-25, 2014.

IBRAF. Instituto Brasileiro de Frutas. Disponível em: $<$ http://www.ibraf.org.br/>. Acesso em: 13 out. 2014.

INSTITUTO ADOLFO LUTZ. Métodos físicoquímicos para análise de alimentos. 4.ed. São Paulo: Instituto Adolfo Lutz, 2008. 1020p.
KAMILOGLU, S.; PASLI, A. A.; OZCELIK, B.; CAMP, J. V.; CAPANOGLU, E. Colour retention, anthocyanin stability and antioxidant capacity in black carrot (Daucus carota) jams and marmalades: Effect of processing, storage conditions and in vitro gastrointestinal digestion. Journal of Functional Foods, London, v.13, p.1-10, 2015a.

KAMILOGLU, S.; PASLI, A.A.; OZCELIK, B.; CAMP, J. V.; CAPANOGLU, E. Influence of different processing and storage conditions on in vitro bioacessibility of polyphenols in black carrot jams and marmalades. Food Chemistry, London, v.186, p.74-82, 2015 b.

KOVACEVIC, D. B.; PUTNIK, P.; DRAGOVICUZELAC, V.; VAHCIC, N.; BABOJELIC, M. S.; LEVAJ, B. Influences of organically and conventionally grown strawberry cultivars on anthocyanins content and color in purees and low sugar jams. Food Chemistry, London, v.181, p.94100,2015 .

LEES, D. H.; FRANCIS, F. J. Standardization of pigment analyses in cranberries. HortScience, St Joseph, v.7, p.83-84, 1972.

LORENZI, H.; BACHER, L.; LACERDA, M.; SARTORI,S. Frutas brasileiras e exóticas cultivadas (de consumo in natura). São Paulo: Instituto Plantarum de Estudos da Flora, 2006. 640p.

NORA, C. D.; MÜLLER, C. D.; BONA, G. S.; RIOS, A. O.; HERTZ, P. F.; JABLONSKI, A.; JONG, E. V.; FLÔRES, S. H. Effect of processing on the stability of bioactive compounds from red guava (Psidium cattleyanum Sabine) and guabiju (Myrcianthes pungens). Journal of Food Composition and Analysis, London, v.34, p.18-25, 2014.

PEREIRA, R. J.; CARDOSO, M. G. Metabólitos secundários vegetais e benefícios antioxidantes. Journal of Biotechnology and Biodiversity, Tocatins, v.3, n.4, p.146-152, 2012.

RUFINO, M. S. M.; ALVES, R. E.; BRITO, E. S.; MORAIS, S. M.; SAMPAIO, C. G.; PÉREZ-JIMÉNEZ, J.; SAURA-CALIXTO, F. D. Metodologia científica: determinação da atividade antioxidante total em frutas pela captura do radical livre $\mathrm{ABTS}^{+}{ }^{+}$. Fortaleza: Embrapa. 2007. (Comunicado Técnico) 
SANTOS, C. O.; BISPO, E. S.; SANTANA, L. R. R.; CARVALHO, R. D. S. Use of "cocoa honey" (Theobroma cacao L) for diet jelly preparation: an alternative technology. Revista Brasileira de Fruticultura, Jaboticabal, v.36, n.3, p.640-648, 2014.

SINGLETON, V. L.; ROSSI, J. A. JR. Colorimetry of total phenolics with phosphomolybdicphosphotungstic acid reagents. American Journal of Enology and Viticulture, David, v.16, p.144-158, 1965.
SPÍNOLA, V.; LLORENT-MARTÍNEZ, E. J.; CASTILHO, P.C. Determination of vitamin C in foods: Current state of method validation. Journal of Chromatography A, Amsterdam, v.1369, p.217,2014

STATSOFT. Programa computacional Statistica 7.0.Tulsa: Statsoft, 2004.

VINCI, G.; BOTRE, F.; RUGGIERI, G. Ascorbic acid in exotic fruits: a liquid chromatographic investigation. Food Chemistry, London, v. 53, n. 2, p. 211-214, 1995. 